\title{
PENERAPAN METODE PEMBELAJARAN THINK PAIR SHARE (TPS) UNTUK MENINGKATKAN HASIL BELAJAR SISWA PADA MATERI LIMIT FUNGSI DI KELAS XI IPA SMA N 1 BUNUT
}

\author{
Morri Manik, Denny Rofika \\ SMA Negeri 1 Bunut, Riau \\ Email : morri.manik@yahoo.com
}

\begin{abstract}
This study aims to improve the learning process and improve learning outcomes by applying the think pair think (TPS) cooperative learning models to class XI science students of SMAN 1 Bunut subject matter Limit Function even semester for the 2016/2017. The low learning outcomes of students of class XI in SMAN 1 Bunut should be suspected because of the lack of student participation, lack of interaction between students and because teachers still tend to use the lecture method in the learning process. This research is a class action research with two cycles. Each cycle consists of two meetings. The research subjects consisted of 24 students. The results showed an improvement in the learning process and an increase in mathematics learning outcomes. Improved learning outcomes can be seen from the results of daily tests I there are 6 students who contributed the development value of 20 and 9 students who contributed the value of development 30. This means that there are 15 students who get a daily test score I is higher than the basic score. In daily test II there were 6 students who contributed 20 developments scores and 14 students who contributed 30 development scores. It means that there were 20 students who got daily II test scores higher than daily test I. Based on the results of this study, it can be concluded that the application of the TPS cooperative learning model can improve the learning process for the better. So that this model may become an alternative model of learning by the teacher when teaching the topic of limit functions.
\end{abstract}

Keywords: Cooperative Learning Model, Technique Thinks Pare Share (TPS), Limit function.

\section{PENDAHULUAN}

Pelajaran Matematika salah satu bidang studi yang diajarkan dalam dunia pendidikan. Pelajaran matematika dalam pelaksanaan pendidikan diberikan kepada semua jenjang pendidikan mulai dari SD hingga SLTA bahkan di Perguruan Tinggi. Tujuan dari pembelajaran matematika adalah agar peserta didik memiliki kemampuan antara lain : 1) memahami konsep matematika, menjelaskan keterkaitan antar konsep dan mengaplikasikan konsep atau algoritma secara luwes, akurat, efisien, dan tepat dalam pemecahan masalah; 2) menggunakan penalaran pada pola dan sifat, melakukan manipulasi matematika dalam membuat generalisasi, menyusun bukti, atau menjelaskan gagasan dan pernyataan matematika; 3) memecahkan masalah yang meliputi kemampuan memahami masalah, merancang model matematika, menyelesaikan model dan menafsirkan solusi yang diperoleh; 4) mengkomunikasikan gagasan dengan simbol, tabel, diagram, atau media lain untuk memperjelas keadaan atau masalah; 5) memiliki sikap menghargai kegunaan matematika dalam kehidupan, yaitu memiliki rasa ingin tahu, perhatian, dan minat dalam mempelajari matematika, serta sikap ulet dan percaya diri dalam pemecahan masalah (BSNP, 2006).

Pentingnya belajar matematika tidak terlepas dari perannya dalam segala jenis dimensi kehidupan. Menurut Badan Standar Nasional Pendidikan (2009), pelajaran matematika perlu diberikan kepada semua peserta didik mulai dari sekolah dasar untuk membekali peserta didik dengan kemampuan berpikir logis, analitis, sistematis, kritis, dan kreatif, serta kemampuan bekerjasama. Oleh karena itu, diharapkan siswa dapat memperoleh hasil belajar yang tinggi dalam belajar matematika.

Penilaian belajar yang diharapkan adalah hasil belajar yang mencapai kriteria ketuntasan minimum. Sesuai dengan ketentuan dari BSNP (2006) bahwa siswa dikatakan tuntas belajar matematika apabila nilai hasil belajar matematika siswa telah mencapai kriteria ketuntasan minimum (KKM) yang ditetapkan sekolah. Namun yang terjadi adalah masih rendahnya hasil belajar siswa. Berdasarkan nilai matematika kelas XI IPA 
SMAN 1 Bunut hanya 10 dari 33 siswa atau $35,8 \%$ siswa kelas XI IPA pada materi pokok statistika yang mencapai KKM yang ditetapkan sekolah yaitu 65. Hal ini menunjukkan bahwa masih banyak siswa kelas XI IPA yaitu $65,2 \%$ siswa yang belum mencapai KKM.

Berdasarkan pengalaman dan pengamatan peneliti terhadap proses pembelajaran matematika siswa kelas XI IPA di SMA Negeri 1 Bunut pada semester genap tahun pelajaran 2016/2017 bahwa pada proses pembelajaran masih terdapat beberapa kekurangan atau kelemahan. Seperti kurang memberikan motivasi dan apersepsi serta memulai pelajaran dengan menjelaskan materi pelajaran dan memberikan contoh soal. Selanjutnya, guru memberikan soal latihan kepada siswa. Guru berusaha melibatkan siswa dengan meminta siswa menuliskan jawaban soal latihan di papan tulis. Namun, hanya siswa berkemampuan tinggi yang aktif. Siswa juga mengalami kesulitan jika soal yang diberikan memiliki bentuk yang berbeda dengan contoh soal yang diberikan. Hal ini terjadi karena siswa kurang memahami konsep materi.

Proses pembelajaran untuk mencapai Kompetensi Dasar (KD) menurut Permendiknas RI nomor 41 tahun 2007 tentang standar proses untuk satuan pendidikan dasar dan menengah pelaksanaan pembelajaran meliputi kegiatan pendahuluan, kegiatan inti dan kegiatan penutup. Kegiatan pendahuluan ditujukan untuk membangkitkan motivasi dan memfokuskan perhatian peserta didik untuk berpartisipasi aktif dalam proses pembelajaran. Kegiatan inti merupakan proses pembelajaran untuk mencapai kompetensi dasar yang dilakukan secara interaktif, inspiratif, menyenangkan, menantang, memotivasi peserta didik untuk berpartisipasi aktif, serta memberikan ruang yang cukup bagi prakarsa, kreativitas, dan kemandirian sesuai dengan bakat, minat, dan perkembangan fisik serta psikologis peserta didik. Kegiatan ini dilakukan melalui proses eksplorasi, elaborasi, dan konfirmasi. Kegiatan penutup dilakukan guru bersama-sama dengan peserta didik membuat rangkuman atau kesimpulan, melakukan penilaian, memberikan umpan balik dan merencanakan kegiatan tindak lanjut (BSNP, 2007).

Berdasarkan uraian di atas disimpulkan bahwa masih terdapat permasalahan dalam proses pembelajaran matematika di kelas XI IPA SMA Negeri 1 Bunut yaitu kurang optimalnya partisipasi aktif siswa dalam proses pembelajaran, guru kurang melibatkan siswa dalam aktivitas belajar secara optimal seperti yang diamanatkan dalam Permendiknas RI Nomor 41 tahun 2007. Optimalnya hasil belajar siswa bergantung pada proses pembelajaran (Sudjana, 2010). Hasil belajar pada dasarnya merupakan akibat dari suatu proses belajar sehingga untuk memperoleh hasil belajar yang optimal maka proses pembelajaran juga harus optimal.

Menanggapi permasalahan di SMAN 1 Bunut terhadap pembelajaran matematika, maka pembelajaran matematika di sekolah khususnya kelas XI IPA perlu suatu model pembelajaran yang sesuai untuk mengatasi masalah tersebut. Suatu model pembelajaran yang dapat mengoptimalkan partisipasi siswa dalam proses pembelajaran serta dapat membantu siswa dalam memahami materi pelajaran guna meningkatkan hasil belajar siswa. Usaha ini dimulai dengan pembenahan proses pembelajaran yang dilaksanakan guru, yaitu dengan menawarkan suatu model pembelajaran yang dapat meningkatkan hasil belajar sekaligus aktivitas siswa. Dari sekian banyak Metode serta Tehnik belajar salah satunya dengan menawarkan model pembelajaran kooperatif teknik Think Pair Square (TPS).

Model pembelajaran kooperatif teknik TPS memberi kesempatan kepada siswa untuk bekerja sendiri serta bekerja sama dengan orang lain. Pada langkah pertama siswa bekerja secara individu agar setiap siswa mengetahui kemampuannya masing-masing, kemudian siswa berdiskusi secara berpasangan sehingga setiap siswa dapat berpartisipasi aktif dalam proses pembelajaran, setelah itu masingmasing pasangan kembali pada kelompok berempat untuk melanjutkan diskusi dengan harapan setiap siswa dapat memahami materi pelajaran dengan lebih jelas. Keunggulan dari teknik ini adalah optimalisasi partisipasi siswa.

Permasalahan adalah apakah penerapan model pembelajaran kooperatif teknik think 
pair square (TPS) dalam proses pembelajaran matematika dapat memperbaiki proses dan meningkatkan hasil belajar matematika siswa kelas XI IPA SMAN 1 Bunut pada materi pokok Limit Fungsi semester genap tahun pelajaran 2016-2017?

\section{METODE}

Bentuk penelitian ini adalah Penelitian Tindakan Kelas (PTK). Penelitian tindakan kelas adalah penelitian yang dilakukan oleh guru di kelasnya sendiri dengan cara (1) merencanakan; (2) melaksanakan; dan (3) merefleksikan tindakan secara kolaboratif dan partisipatif dengan tujuan memperbaiki kinerjanya sebagai guru, sehingga hasil belajar siswa dapat meningkat (Kusumah, 2009). Penelitian ini dilakukan secara kolaboratif, yaitu peneliti dan guru bekerjasama dalam proses pelaksanaan tindakan. Pelaksanaan tindakan oleh peneliti sendiri dan guru sebagai pengamat selama proses pembelajaran.

Arikunto,dkk (2009) menyatakan bahwa secara garis besar, setiap siklus dalam penelitian tindakan kelas dilaksanakan melalui empat tahap, yaitu: perencanaan, pelaksanaan, pengamatan, dan refleksi.

Data yang dikumpulkan pada penelitian ini adalah data kualitatif dan data kuantitatif. Data kualitatif berupa data aktivitas siswa dan aktivitas guru selama proses pembelajaran. Data aktivitas siswa dan guru selama proses pembelajaran dikumpulkan dengan menggunakan lembar pengamatan. Data kuantitatif berupa data hasil belajar matematika siswa setelah proses pembelajaran. Data ini diperoleh dari hasil tes matematika siswa. Data hasil tes digunakan untuk menentukan ketercapaian KKM, skor perkembangan siswa dan keberhasilan tindakan.

Lembar pengamatan yang digunakan dalam penelitian ini adalah lembar pengamatan terfokus. Lembar pengamatan terfokus berisi aspek-aspek aktivitas guru dan siswa yang menjadi fokus pengamatan selama proses pembelajaran (Sukarno,2009). Aspek-aspek aktivitas guru dan siswa yang diamati disesuaikan dengan penerapan pembelajaran kooperatif teknik Think Pair Square (TPS).

Teknik observasi dilakukan dengan menggunakan lembar pengamatan.
Pengamatan dilakukan oleh guru matematika yang mengajar di kelas XI IPA SMAN 1 Bunut. Pengamatan dilakukan disetiap pertemuan. Pengamatan dilakukan dengan mengisi lembar pengamatan yang telah disediakan. Pengamatan yang dilakukan meliputi pengamatan tentang aktivitas guru dan aktivitas siswa selama proses pembelajaran.

Data hasil belajar siswa dikumpulkan melalui tes hasil belajar yang mencakup materi pokok Peluang. Tes hasil belajar dibuat berdasarkan indikator-indikator yang ingin dicapai pada materi pokok Peluang. Tes hasil belajar diberikan pada ulangan harian I dan ulangan harian II. Ulangan harian I dilaksanakan pada siklus pertama setelah melalui tigakali pertemuan. Ulangan harian II dilaksanakan pada siklus kedua setelah melalui empat kali pertemuan.

Persenta sejumlah siswa yang mencapai KKM dapat dihitung dengan menggunakan rumus sebagai berikut :

Persentase ketercapaian

$K K M=\frac{\text { jumlah siswa yang mencapai } K K M}{\text { jumlah siswa keseluruhan }} \times 100 \%$

Menurut Suyanto (2007) tindakan dikatakan berhasil jika hasil belajar yang dicapai setelah tindakan lebih baik. Dengan kata lain, tindakan dikatakan berhasil jika frekuensi siswa yang mencapai KKM setelah tindakan bertambah dari sebelumnya. Peningkatan ini dapat dilihat dari perkembangan skor dasar, ulangan harian I dan ulangan harian II.

a) Analisis distribusi frekuensi hasil belajar

Seluruh data hasil belajar matematika siswa akan disajikan dalam bentuk tabel distribusi frekuensi, dengan menyajikan data dalam bentuk tabel distribusi frekuensi dapat diperoleh gambaran yang ringkas dan jelas mengenai data hasil belajar siswa. Tabel distribusi frekuensi adalah alat penyajian data statistik yang berbentuk kolom dan lajur, yang di dalamnya dimuat angka yang dapat melukiskan atau menggambarkan pencaran atau pembagian frekuensi dari variabel yang sedang menjadi objek penelitian.

\section{HASIL DAN PEMBAHASAN}

Berdasarkan uraian di atas dapat dilihat bahwa tidak semua siswa mencapai KKM 
untuk setiap indikator. Siswa melakukan kesalahan dalam menentukan rumus yang digunakan. Ketercapaian KKM untuk seluruh indikator pada ulangan harian II dari 24 siswa terdapat 13 siswa yang memperoleh nilai $\geq 60$ dengan persentase $54,2 \%$. Terdapat 11 siswa yang belum mencapai KKM. Nilai terendah yang diperoleh siswa pada ulangan harian II adalah 32 .

Ketercapaian Kriteria Ketuntasan Minimum (KKM) pada materi peluang secara keseluruhan disajikan dalam tabel berikut.

Tabel 1. Persentase Ketercapaian KKM Siswa

\begin{tabular}{lccc}
\hline & $\begin{array}{c}\text { Skor } \\
\text { Dasar }\end{array}$ & $\begin{array}{c}\text { Ulangan } \\
\text { Harian I }\end{array}$ & $\begin{array}{c}\text { Ulangan } \\
\text { Harian II }\end{array}$ \\
\hline $\begin{array}{l}\text { Jumlah } \\
\text { Siswa yang } \\
\text { mencapai }\end{array}$ & 7 & 9 & 13 \\
$\begin{array}{l}\text { KKM } \\
\begin{array}{l}\text { Persentase } \\
(\%)\end{array}\end{array}$ & 29,17 & 37,5 & 54,2 \\
\hline
\end{tabular}

Berdasarkan tabel di atas terlihat bahwa terjadi peningkatan jumlah siswa yang mencapai KKM dari skor dasar ke ulangan harian I dan peningkatan jumlah siswa yang mencapai KKM dari ulangan harian I ke ulangan harian II. Dengan demikian tindakan dikatakan berhasil.

Untuk mengetahui peningkatan nilai hasil belajar siswa kelas XI SMAN 1 Bunut sebelum dan setelah tindakan dapat dilihat pada tabel daftar distribusi frekuensi berikut :

Tabel 2. Daftar Distribusi Frekuensi Hasil Belajar Siswa

\begin{tabular}{cccc}
\hline \multirow{2}{*}{ Interval } & \multicolumn{3}{c}{ Frekuensi Siswa } \\
\cline { 2 - 4 } & $\begin{array}{c}\text { Skor } \\
\text { Dasar }\end{array}$ & $\begin{array}{c}\text { Nilai UH } \\
\text { I }\end{array}$ & $\begin{array}{c}\text { Nilai UH } \\
\text { II }\end{array}$ \\
\hline $17-30$ & 8 & 5 & 0 \\
$31-44$ & 3 & 8 & 1 \\
$45-58$ & 6 & 2 & 10 \\
$59-72$ & 4 & 4 & 3 \\
$73-86$ & 3 & 3 & 3 \\
$87-100$ & 0 & 2 & 7 \\
\hline$\sum \boldsymbol{f}$ & $\mathbf{2 4}$ & $\mathbf{2 4}$ & $\mathbf{2 4}$ \\
\hline
\end{tabular}

Berdasarkan tabel distribusi frekuensi tersebut, terlihat bahwa terjadi perubahan hasil belajar antara skor dasar, ulangan harian I, dan ulangan harian II. Dari skor dasar ke ulangan harian I, frekuensi siswa yang memperoleh nilai rendah (17-30) menurun. Frekuensi siswa yang memperoleh nilai tinggi (87-100) mengalami peningkatan. Artinya, terjadi peningkatan hasil belajar matematika siswa dari skor dasar ke ulangan harian I. Hal ini menunjukkan bahwa tindakan yang dilakukan pada penelitian ini memberikan pengaruh terhadap hasil belajar matematika siswa.

Dari tabel dapat dilihat juga perubahan distribusi frekuensi hasil belajar siswa mengalami perubahan dari ulangan harian I ke ulangan harian II. Jumlah siswa yang memperoleh nilai rendah (17-30) menurun. Sedangkan jumlah siswa yang memperoleh nilai tinggi (87-100) mengalami peningkatan. Artinya, pelaksanaan tindakan pada siklus II tetap memberikan peningkatan hasil belajar matematika siswa. Sehingga dapat disimpulkan bahwa tindakan berhasil atau dengan kata lain penerapan model pembelajaran kooperatif teknik Think Pair Square (TPS) dapat meningkatkan hasil belajar matematika siswa kelas XI IPA SMAN 1 Bunut.

Artinya, pelaksanaan tindakan pada siklus II memberikan peningkatan hasil belajar matematika siswa. Sehingga dapat disimpulkan bahwa tindakan berhasil atau dengan kata lain penerapan model pembelajaran kooperatif teknik Think Pair Square (TPS) dapat meningkatkan hasil belajar matematika siswa.

Berdasarkan hasil pengamatan aktivitas guru dan siswa dapat dikatakan bahwa penerapan model pembelajaran kooperatif teknik Think Pair Square (TPS) mengalami peningkatan pada setiap pertemuan, proses pembelajaran semakin membaik dan sesuai dengan rencana pelaksanaan pembelajaran (lampiran B). Aktivitas guru telah sesuai dengan perencanaan dan siswa juga sudah semakin terbiasa dengan model pembelajaran yang diterapkan guru. Siswa berpartisipasi aktif dalam diskusi kelompok. Siswa juga sudah mulai percaya diri untuk tampil di depan kelas.

Berdasarkan analisis nilai perkembangan siswa dan penghargaan kelompok, terlihat bahwa pada ulangan harian I ada 6 siswa yang menyumbangkan nilai perkembangan 20 dan 9 siswa yang menyumbangkan nilai perkembangan 30 . Ini menunjukkan bahwa ada 15 siswa yang memperoleh nilai ulangan harian I lebih tinggi dari skor dasar. Sehingga penghargaan kelompok pada siklus I terdiri dari dua kelompok baik, tiga kelompok hebat, dan satu 
kelompok super. Pada ulangan harian II terdapat 6 siswa yang menyumbangkan nilai perkembangan 20 dan 14 siswa yang menyumbangkan nilai perkembangan 30 . Hal ini menunjukkan bahwa ada 20 siswa yang memperoleh nilai ulangan harian II lebih tinggi dari ulangan harian I. Ini menunjukkan bahwa kerjasama kelompok semakin baik sehingga terjadi peningkatan jumlah siswa yang memperoleh nilai sama atau lebih tinggi dari skor dasar. Peningkatan ini mengakibatkan penghargaan kelompok juga meningkat. Pada siklus II, terdapat satu kelompok yang mendapat penghargaan sebagai kelompok baik, satu kelompok hebat dan empat kelompok super.

Berdasarkan ketercapaian KKM indikator, tidak semua siswa yang mencapai KKM untuk setiap indikator. Kesalahankesalahan yang dilakukan siswa antara lain adalah dalam menentukan rumus yang digunakan untuk menyelesaikan permasalahan yang diberikan, kesalahan dalam memahami soal, dan kesalahan melakukan perhitungan. Berdasarkan analisis ketercapaian KKM siswa, persentase jumlah siswa yang mencapai KKM mengalami peningkatan dari skor dasar ke ulangan harian I dan dari ulangan harian I ke ulangan harian II. Berdasarkan analisis distribusi frekuensi data hasil belajar, hasil belajar siswa juga mengalami peningkatan. Jumlah siswa yang memperoleh nilai rendah menurun dan jumlah siswa yang memperoleh nilai tinggi meningkat.

Penerapan model pembelajaran kooperatif teknik Think Pair Square (TPS) pada proses pembelajaran siswa kelas XI IPA SMAN 1 Bunut Kabupaten Pelalawan telah dapat memberikan dampak positif pada pelaksanaan proses pembelajaran di kelas tersebut. Siswa menjadi lebih aktif dalam kegiatan pembelajaran sehingga proses pembelajaran tidak lagi didominasi oleh guru. Siswa juga lebih termotivasi untuk membangun pengetahuannya dan berpartisipasi aktif dalam kegiatan diskusi kelompok sehingga siswa dapat lebih memahami konsep materi. Hal ini memberikan pengaruh terhadap hasil belajar siswa. Jadi, hasil analisis tindakan ini mendukung hipotesis tindakan yang diajukan yaitu penerapan model pembelajaran kooperatif teknik Think Pair
Square (TPS) dapat meningkatkan hasil belajar matematika siswa kelas XI IPA SMAN 1 Bunut Kabupaten Pelalawan pada materi pokok Peluang semester ganjil tahun ajaran 2016-2017.

Pada pelaksanaan proses penelitian, terdapat beberapa kekurangan dalam penyajian LKS terutama pada LKS 3 dan LKS 4. Guru belum menyajikan langkah penemuan konsep dengan tepat dan rinci sehingga siswa mengalami kesulitan dalam menyimpulkan generalisasi penerapan aturan kombinasi pada penjabaran Binom Newton. Oleh karena itu, pada pertemuan ini guru mengalami kendala waktu karena banyak memberikan bimbingan pada siswa. Pada penyajian LKS 4, langkahlangkah untuk menentukan definisi kejadian belum jelas. Kekurangan juga terjadi pada penyajian LKS 1. Pada penerapan aturan perkalian, guru kurang memberikan penguatan dalam menanamkan konsep aturan perkalian dengan syarat tertentu sehingga pada saat diberikan soal ulangan harian banyak siswa yang melakukan kesalahan dalam menentukan penempatan objek pada penerapan aturan perkalian.

\section{SIMPULAN}

Pada pelaksanaan penelitian terdapat beberapa kendala, di antaranya dalam efisiensi waktu, pada pertemuan pertama siswa masih bingung dengan model pembelajaran yang diterapkan. Siswa juga kurang aktif mengikuti kegiatan pembelajaran. Kekurangankekurangan ini menjadi bahan perbaikan bagi guru untuk pertemuan berikutnya. Guru berusaha melibatkan siswa agar lebih aktif dan siswa juga mulai terbiasa dengan model pembelajaran yang diterapkan sehingga pada pertemuan berikutnya siswa lebih aktif dan antusias dalam mengikuti kegiatan pembelajaran. Selain itu, kurangnya efisiensi waktu juga mengakibatkan siswa tidak mempunyai cukup waktu untuk menyelesaikan soal latihan pada kegiatan akhir sehingga guru tidak dapat mengetahui tingkat pemahaman setiap siswa pada setiap pertemuan. Kendala lain adalah karena kegiatan pembelajaran dilaksanakan pada jam terakhir sehingga konsentrasi siswa sudah berkurang. Guru mengatasi kendala ini dengan berusaha 
PRINSIP Pendidikan Matematika

Volume 2, Nomor 1, November 2019

membuat siswa tidak terlalu kaku dalam mengikuti kegiatan pembelajaran.

\section{DAFTAR PUSTAKA}

Arikunto, S., Suhardjono, Supardi. (2009). Penelitian Tindakan Kelas. Jakarta: Bumi Aksara.

BSNP. (2007). Salinan Lampiran Peraturan Menteri Pendidikan Nasional Republik Indonesia Nomor 41 Tahun 2007 tentang Standar Proses untuk Satuan Pendidikan Dasar dan Menengah. Jakarta: BSNP

Dimyati dan Mudjiono. (2006). Belajar dan Pembelajaran. Jakarta: Rineka Cipta

Iskandar. (2009). Penelitian Tindakan Kelas. Ciputat: Gaung Persada Press

Lie, A. (2007). Cooperative Learning Mempraktikkan Kooperatif Learning di Ruang-ruang Kelas. Jakarta: Grasindo

Kusumah,W. (2009). Mengenal Penelitian Tindakan Kelas. Jakarta: PT. Indeks

Purwanto. (2009). Evaluasi Hasil Belajar. Yogyakarta: Pustaka Belajar.
Riyanto, Y. (2010). Paradigma Baru Pembelajaran. Surabaya: Kencana

Sanjaya, W. (2009). Strategi Pembelajaran Berorientasi Standar Proses Pendidikan. Jakarta: Kencana

Sardiman, A.M. (2008). Interaksi dan Motivasi Belajar Mengajar. Jakarta: Raja Grafindo Persada

Slameto. (2010). Belajar dan faktor-faktor yang Mempengaruhinya Edisi Revisi. Jakarta: Rineka Cipta

Sudijono, A. (2009). Pengantar Statistik Pendidikan. Jakarta: Raja Grafindo Persada

Sudjana, N. (2010). Penilaian Hasil Proses Belajar Mengajar. Bandung: Remaja Rosdakarya

Sukarno. (2009). Penelitian Tindakan Kelas. Surakarta: Media Perkasa

Uno, H.B. (2009). Perencanaan Pembelajaran. Jakarta: Bumi Aksara 